\title{
A Survey of the Elderly in Regional Cities on their Attitudes toward Driving and Giving Up Driving*
}

\author{
Misato NIHEI** and Minoru KAMATA*** \\ ${ }^{* *}$ Department of Mechanical Engineering, the University of Tokyo, \\ 7-3-1 Hongo, Bunkyo-ku, Tokyo 113-8656, JAPAN \\ E-mail: mnihei@sl.t.u-tokyo.ac.jp \\ ${ }^{* * *}$ Institute of Gerontology, the University of Tokyo, \\ 7-3-1 Hongo, Bunkyo-ku, Tokyo 113-8656, JAPAN \\ E-mail: kamata@mech.t.u-tokyo.ac.jp
}

\begin{abstract}
Elderly drivers are increasing every year in Japan. However, physical depression caused by aging is also a cause of traffic accidents and they will all have to give up driving one day. The aim of this study is to clarify the effects of car dependency and the impact of having to stop driving among the elderly. And to propose alternative transportation options for elderly after having surrendered their driver's licenses. We carried out a questionnaire survey and a focus group interview. During this study, we sent 1338 questionnaires to people over 60 years old in regional cities that included areas with convenient access and inconvenient access to public transit. From our survey, we found that, over half of the elderly drive every day, the older people lower drive frequency. License holder of elderly with feelings of decreased motor skills awareness a decrease in driving ability. Moreover it is clarified that issue of alternative mobility are "mobility devices to maintain social and personal relationships" and "mobility devices as an extension of walking" and "use the existing public transport environment".
\end{abstract}

Key words: Elderly Driver, Questionnaire, Focus Group Interview, Giving Up Driving

\section{Introduction}

In Japan, there are more than 29 million people over 65 years old, and the number of elderly drivers is increasing every year. However, the deterioration in physical and cognitive skills caused by aging is a cause of traffic accidents, and at some point an elderly person has to give up driving ${ }^{(1)(2)}$. The inability to meet set standards of vehicular operation will eventually force elderly people to give up driving. However, for many elderly drivers, the automobile is their main means of transportation, and an elderly driver may not want to lose the ability to actively take part in daily activities in an independent manner ${ }^{(3)(4)}$. On the other hand, for an elderly person to keep driving so as to be able to go shopping or to the hospital could lead to traffic accidents ${ }^{(5)}$. Therefore, clarifying the effects of the elderly handing in their driver's licenses is an important issue in preventing vehicular accidents. How to encourage the elderly to stop driving if medically indicated, while maintaining an active daily life, is an issue that needs to be decided based on the perspectives of all parties concerned, and includes factors such the specific car-dependency of elderly drivers in remaining able to maintain their lifestyles. Moreover, 
when the transport dependency and requirements of the elderly driver are made clear, it will be possible to propose alternative transportation methods more specific.

Small vehicles have been found to be useful for an alternative transportation vehicle for the elderly. Kamata et al. proposed in 2002 a new compact electric vehicle (EV) for elderly dubbed a Silver Vehicle, and they concluded that offering EVs to elderly people would help them maintain the mobility and raise their quality of life $(\mathrm{QOL})^{(6)(7)(8)}$. In recent years, a vehicle development project for a human-friendly vehicle suitable for elderly people, the Next-generation Car Project, has been in the works in Fukuoka Prefecture ${ }^{(9)}$.

The aims of this study are to clarify the effects of car dependency and the impact of having to stop driving among the elderly, and to propose alternative transportation options for elderly people who have surrendered their driver's licenses in rural areas.

In this survey, we select as our target area Fukui Prefecture, which has one of the highest car ownership rates in the nation. Fukui Prefecture in 2008 had 534,980 car owners, including 88,134 people classified as elderly such as over-65s (aging rate 16.5\%), Compared to 10 years ago, the aging rate of driver's license holders has increased 5.8\%. On a related subject, the number of traffic accidents caused by elderly people in 2008 were "accidents causing injury" 647(16.1\%) and "accidents causing death" 21 (38.2\%). The prefecture introduced a system in 1998 under which people could voluntarily hand in their driver's license, and the system is aimed at drivers who are aware that their physical skills are deteriorating, and elderly drivers and others who are not confident of driving independently. In addition, a "past driving career certificate" has been issued as an alternative identification card for the elderly since 2002 .

\section{Methodology}

\subsection{Questionnaire Survey}

We carried out a questionnaire survey and a focus group interviews. We sent out questionnaires to 1,338 people over 60 years old in two cities (Fukui City: 600, Sakai City: 738) that included areas that have both well served and poorly served by public transport. The recipients of the questionnaire were chosen based on random sampling using the Basic Resident Registers for the two cities. We extracted three kinds of areas that have different degrees of convenience in terms of public transport in each city.

The questionnaire asked:

- For driver's license holders: Frequency and purpose of driving, what is the appropriate age to give up driving? and had they noticed any symptoms indicating physical deterioration that would affect their body functions and driving abilities

- For those who have surrendered their driver's license: Reason for and process in doing so, and whether they have any feelings of unease or felt a loss of mobility after giving up driving.

- For all respondents: Profile of the recipient: their state of health, and their usage of public transport.

The response sampling was $57.3 \%$. For reference, the population of Fukui City is about 270,000 , and for Sakai City it is 10,000 . As a comparison, the population of Tokyo is around 13 million.

\subsection{Focus Group Interview}

Based on the result of the questionnaire survey, we carried out quantitative survey, focus group interview, to analyze the details of the attitude of elderly people toward driving in 
each area. We selected 4 areas from the 6 areas covered in the questionnaire survey. We chose both male and female participants in each of the 4 areas. Each group in an area consisted of 6 to 9 elderly participants. During the interview, we:

- Asked the participants to fill in a questionnaire detailing: Driving cessation (when they had stopped or planned to stop driving), were they careful about driving, were they aware of their driving abilities, the number of cars owned by their families , driving purpose and profile (state of health, family details)

- Asked the participants about work: We asked them to plot their homes and regular destinations on a map, and write down the purpose of the trips (hospital, shopping, job and hobbies), driving frequency, the route taken, and mode of transport used.

\section{Questionnaire survey - attribution and driving cessation-}

\subsection{Total information}

We received 760 questionnaires. Table 1 shows the driving statuses and age groups of the respondents. The percentages of respondents broken down by driver's license status were: $62.4 \%(\mathrm{n}=474)$, non-licensed $34.2 \%(\mathrm{n}=260)$, those who had returned their license $3.4 \%(\mathrm{n}=26)$. Compared with other age groups, the over-75 group was more conscious about having to stop driving. We also found that the more frequently people drove, the more they wanted to hold onto their licenses.

Table 1 Respondents and age-groups

\begin{tabular}{ccccc}
\hline \hline Age-group & Licensed & Non-licensed & Returned license & Total \\
\hline 60 to 64 & 166 & 24 & 0 & 190 \\
(Male, Female) & $(82,83)$ & $(7,17)$ & 0 & 283 \\
65 to 74 & 197 & 81 & 5 & \\
(Male, Female) & $(124,73)$ & $(9,72)$ & $(1,4)$ & 287 \\
Over 75 & 111 & 155 & 21 & 760 \\
(Male, Female) & $(92,19)$ & $(26,129)$ & $(18,3)$ & 26 \\
Total & $\begin{array}{c}474 \\
(62.4 \%)\end{array}$ & $\begin{array}{c}260 \\
(34.2 \%)\end{array}$ & $(3.4 \%)$ & 760 \\
\hline
\end{tabular}

\subsubsection{Age}

Figure 1 shows the purpose of going out by age group. For all age groups, the most frequent purposes for going out were shopping and visiting the hospital, activities that are necessary for life and life support. As for other reasons for going out, in the "middle" age group (60 to 64), working was one of the main purposes. In the "young-old" age group (65 to 74) recreation was cited as a reason, and in the "old-old" age group (over 75) agriculture was the main purpose. Figure 2 shows the average frequencies of going out and driving in a week. The result shows the frequency of going out decreases with age, in particular the decrease in going out was quite variable in the "old-old" age group.

Table 3 shows the chi-square test results for mode of transport, frequency and satisfaction about their current mobility between the "young-old" and the "old-old" age groups. The rate of using own car or taxi for the "young-old" age group compared with the "old-old" age group was significantly lower. Moreover, the rate of traveling in another person's car for the "old-old" age group compared with the "young-old" age group was significantly lower. The driving frequency of the "old-old" age group compared with the "young-old" age group was significantly lower. Satisfaction about their current mobility for the "old-old" age group was significantly lower compared with the "young-old" age group. Furthermore, public transportation use was less than $10 \%$ use in the "young-old" age group (except public bus use) and $13.1 \%$ for the "old-old" age group. 
Table 2 Mobility and aging

\begin{tabular}{|c|c|c|c|c|}
\hline & $\begin{array}{c}\text { "Young-old", } \\
65-74 \\
\text { Number (\%) }\end{array}$ & $\begin{array}{c}\text { "Old-old", } \\
\text { over } 75 \\
\text { Number }(\%)\end{array}$ & $\begin{array}{c}\chi^{2} \\
\text { value }\end{array}$ & $p$ value \\
\hline \multicolumn{5}{|l|}{ Trip device } \\
\hline Use own car & $176 \quad(64.0)$ & $93 \quad(33.9)$ & 49.62 & $0.00 * *$ \\
\hline Another's car & 70 & $96 \quad(35.0)$ & 6.87 & $0.032 *$ \\
\hline Taxi & $5 \quad(1.8)$ & $20 \quad(7.3)$ & 10.39 & $0.006 * *$ \\
\hline $\begin{array}{l}\text { Satisfaction } \\
\text { current mobility }\end{array}$ & $331(92.2)$ & 354 (84.4) & 6.327 & $0.012 *$ \\
\hline $\begin{array}{l}\text { Going out frequency } \\
3 \text { to } 7 / \text { week }\end{array}$ & $175(92.6)$ & $88(83.0)$ & 6.44 & $0.011^{*}$ \\
\hline
\end{tabular}

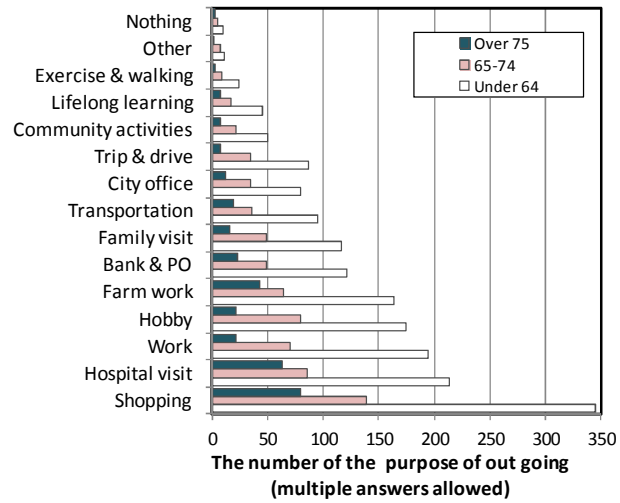

Fig. 1 The purpose of out going

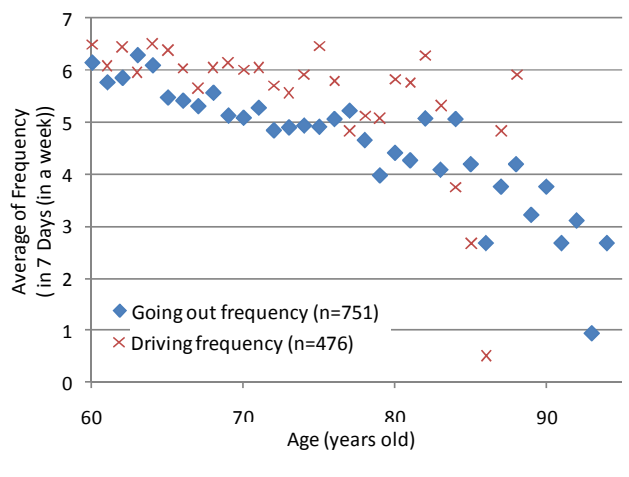

Fig. 2 Going out and driving frequency

\subsubsection{Gender}

Table 3 shows the chi-square test results for: purpose of trip, mode of transport, driving frequency, and satisfaction about their current mobility between male and female participants. For men, working and walking were cited as the main purposes for going out; while for women, shopping and going to the hospital were the main purposes. Moreover, the rate of using their own car for women was significantly lower compared with men; whereas, the rate of using another's vehicle (e.g. spouse's) was significantly higher for women than for men. Driving frequency was almost the same between men and women. Satisfaction about their current mobility was significantly lower for women than for men.

The rate of usage of public transportation (bus only) by women was significantly higher than for men.

Table 3 Mobility and gender

\begin{tabular}{|c|c|c|c|c|}
\hline & $\begin{array}{c}\text { Male } \\
\text { Number (\%) } \\
\end{array}$ & $\begin{array}{c}\text { Female } \\
\text { Number (\%) }\end{array}$ & $x^{2}$ value & $p$ value \\
\hline $\begin{array}{l}\text { Purpose of trip } \\
\text { Hospital } \\
\text { Shopping }\end{array}$ & $\begin{array}{cc}99 & (29.7) \\
187 & (56.2)\end{array}$ & $\begin{array}{ll}144 & (38.0) \\
264 & (69.7)\end{array}$ & $\begin{array}{c}5.39 \\
14.31\end{array}$ & $\begin{array}{c}0.02 * * \\
0.003\end{array}$ \\
\hline $\begin{array}{l}\text { Mode of transport } \\
\text { Own car } \\
\text { Another's car } \\
\text { Bicycle }\end{array}$ & $\begin{array}{cc}270 & (78.0) \\
51 & (14.7) \\
72 & (20.6)\end{array}$ & $\begin{array}{ll}156 & (39.6) \\
155 & (39.3) \\
118 & (29.9)\end{array}$ & $\begin{array}{l}111.44 \\
55.50 \\
8.07\end{array}$ & $\begin{array}{l}0.00^{* *} \\
0.00^{* *} \\
0.018^{*}\end{array}$ \\
\hline $\begin{array}{l}\text { Driving frequency } \\
\text { More than } 3 \text { times } \\
\text { a week }\end{array}$ & $264 \quad(92.3)$ & $155 \quad(89.1)$ & 1.39 & 0.156 \\
\hline $\begin{array}{l}\text { Satisfaction with } \\
\text { current mobility }\end{array}$ & $331 \quad(92.2)$ & $354 \quad(86.6)$ & 6.33 & $0.012 *$ \\
\hline $\begin{array}{ll}\begin{array}{l}\text { Public } \\
\text { (bus) }\end{array} & \text { transport } \\
\end{array}$ & $16 \quad(5.0)$ & $48 \quad(13.9)$ & 18.00 & $0.00 * *$ \\
\hline
\end{tabular}




\subsubsection{Driving situation and characteristics of region}

We extracted three kinds of areas that have different degrees of public transport convenience. Figure 3 and Table 4 show the characteristics in each city. Figure 4 shows the mobility methods for each area. As for own-car usage, both areas with a low accessibility by public transport ( $\mathrm{Hongo}=44.1 \%$; Maruoka $=39.9 \%$ ) and areas with a high accessibility by public transport (Sakai $=46.2 \%$ ) tend to have a high percentage of own-car usage than other areas. As for walking, areas with average accessibility by public transport (Haruyama $=34 \%$; Harue $=32.7 \%$ ) tend to a higher percentage of walking case than other areas. In addition to the two main purposes of shopping and going to the hospital, other trip purpose are agricultural work in areas with both low and high accessibility by public transport (Hongo, Maruoka and Sakai), hobbies/past-times in areas of average and high accessibility by public transport (Haruyama, Nakafujishima), and work in areas of average and high accessibility by public transport (Nakafujishima, Harue, Sakai). Figure 5 shows the frequency of going out in each area. In all areas, $43.6 \%$ of the participants go out every day, and around 70 people go out three or more times a week.

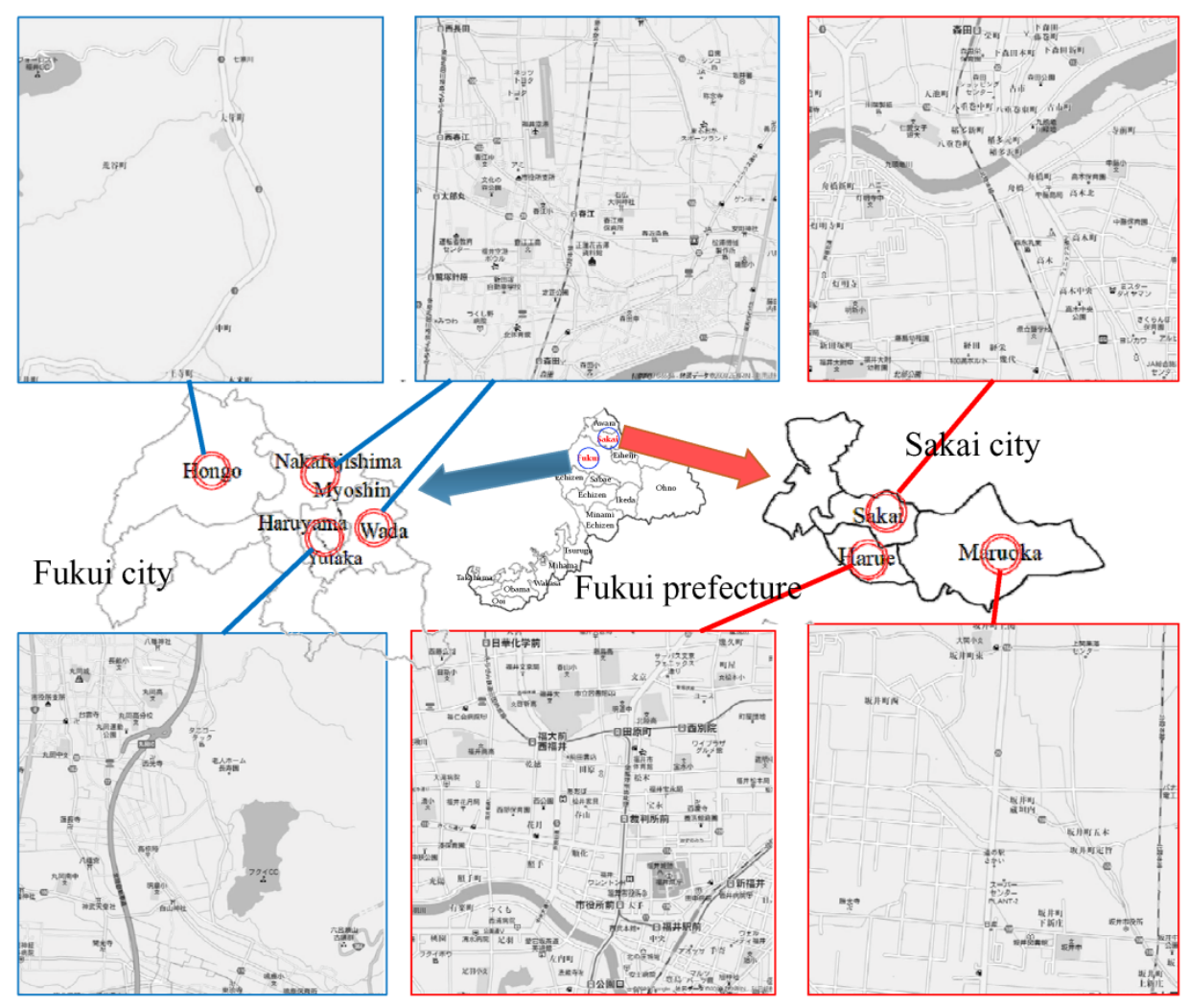

Figure 3 Research area (map data (C2011 ZENRIN) 
Table 4 Object areas

\begin{tabular}{|c|c|c|c|}
\hline & & Fukui-city & Sakai-city \\
\hline \multirow{3}{*}{$\begin{array}{l}\text { Classification } \\
\text { of } \\
\text { accessibility }\end{array}$} & Low & $\begin{array}{l}\text { Hongo (Low): Away from } \\
\text { a central city and public } \\
\text { transport route } \\
\text { Population, aging rate } \\
\qquad 1159,31.06 \% * *\end{array}$ & $\begin{array}{l}\text { Maruoka (Low): Near a public } \\
\text { transport rout, but away from a } \\
\text { central city and public transport } \\
\text { route } \\
\text { Population, aging rate } \\
\qquad 32,461,19.0 \% *\end{array}$ \\
\hline & Middle & $\begin{array}{l}\text { Haruyama (Middle): } \\
\text { Slightly away from a } \\
\text { central city and public } \\
\text { transport route } \\
\text { Population, aging rate } \\
\qquad 6,907,28.93 \% * *\end{array}$ & $\begin{array}{l}\text { Harue (Middle): Near a public } \\
\text { transport rout, but away from a } \\
\text { central city and public transport } \\
\text { route } \\
\text { Population, aging rate } \\
\qquad 23.05,18.0 \% *\end{array}$ \\
\hline & $\begin{array}{l}\text { High } \\
\text { accessible } \\
\text { area }\end{array}$ & $\begin{array}{l}\text { Nakafujishima (High): } \\
\text { near a central city and } \\
\text { public transport route } \\
\text { Population, aging rate } \\
\qquad 4,241,26.97 \% * *\end{array}$ & $\begin{array}{l}\text { Sakai (High): Near the central } \\
\text { city, public transport route and } \\
\text { community bus route } \\
\text { Population, aging rate } \\
\qquad 12,953,21.8 \% *\end{array}$ \\
\hline
\end{tabular}

${ }^{*} \mathrm{H} 17,{ }^{*} \mathrm{H} 22$

Figure 6 shows driving frequency. More than $85 \%$ of respondents drive three or more times a week in all areas. Figure 7 shows the degree of satisfaction with mobility for each area. Around $90 \%$ are satisfied with their mobility in all areas. As for public transport, around $10 \%$ use the train (Harue $=14.9 \%$; Haruyama $=9.0 \%$ ) and around $12 \%$ use the bus $($ Haruyama $=19.2 \%$; Hongo $=13.8 \%$, Nakafujishima $=8.1 \%$ ) three or more times a month. There is need for more public transportation in Hongo (68\%), but there is less need in other 5 areas (more than $60 \%$ of respondents said they did not need more public transport).
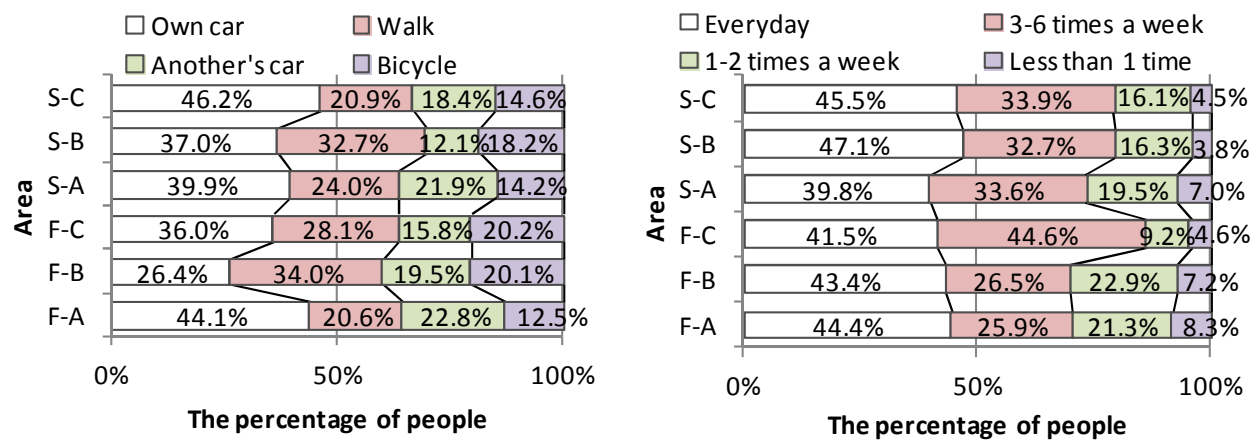

F-A Hongo, F-B Haruyama, F-C Nakafujishima, S-A Maruoka, S-B Harue, S-C Sakai

Fig. 4 Mobility method

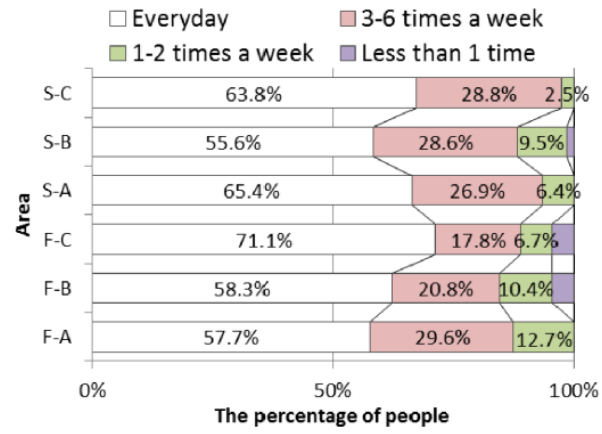

Fig. 5 Mobility frequency

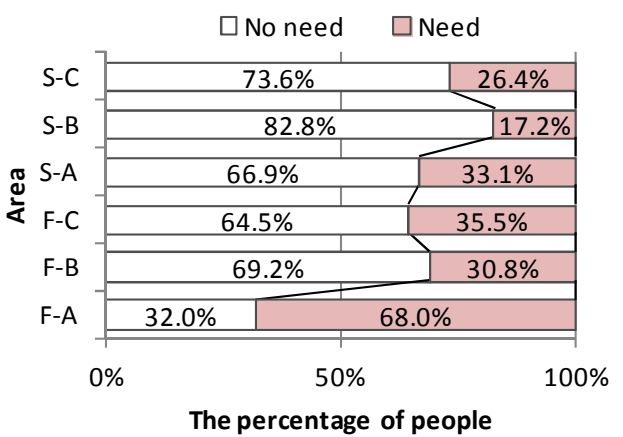

F-A Hongo, F-B Haruyama, F-C Nakafujishima, S-A Maruoka, S-B Harue, S-C Sakai

Fig. 6 Driving frequency

Fig. 7 Needs of public transportation 


\subsection{Driving cessation}

As for ceasing to drive, the desire to continue driving for less than five years/more than five years was compared by age, gender, family structure (average number: 3.86) and driving frequency. The results of the chi-square test are shown in Table 5, and show a significant difference between the desire to continue driving and age, and driving frequency (gender and family structure are not significant).

Table 5 Desire (in years) to continue driving

\begin{tabular}{|c|c|c|c|c|}
\hline \multirow{2}{*}{$\begin{array}{l} \\
\\
\end{array}$} & 4 or less years & 5 or more years & \multirow{2}{*}{$\chi^{2}$ value } & \multirow{2}{*}{$\mathrm{p}$ value } \\
\hline & Number $(\%)$ & Number $(\%)$ & & \\
\hline \multicolumn{5}{|l|}{ Age (years old) } \\
\hline YE: $65-74$ & $15 \quad(8.0)$ & $173 \quad(92.0)$ & 74.80 & $0.00 * *$ \\
\hline OO: over 75 & $54 \quad(53.5)$ & $47 \quad(46.5)$ & & \\
\hline \multicolumn{5}{|l|}{ Gender } \\
\hline Male & $50 \quad(18.0) / 278$ & $228 \quad(82.0)$ & 0.623 & 0.430 \\
\hline Female & $26 \quad(15.1) / 172$ & $146 \quad(84.9)$ & & \\
\hline \multicolumn{5}{|l|}{ Family structure } \\
\hline Single or double & $23 \quad(16.0)$ & $121 \quad(84.0)$ & 0.128 & 0.72 \\
\hline Over three & $52 \quad(17.3)$ & $248 \quad(82.7)$ & & \\
\hline \multicolumn{5}{|l|}{ Driving frequency } \\
\hline 3 to 7 times a week & $56 \quad(13.9)$ & $346 \quad(86.1)$ & 1584 & $000 * *$ \\
\hline $\begin{array}{l}\text { Less than } 2 \text { times a } \\
\text { week }\end{array}$ & $24 \quad(61.5)$ & $24 \quad(61.5)$ & 15.04 & 0.00 \\
\hline YE: Young-Old & & & & \\
\hline
\end{tabular}

4. Questionnaire survey: deterioration of physical skills and its effect on driving on driving

\subsection{Methodology of Analyses}

To estimate the impact of the deterioration of physical and sensory functions on driving skills, we compared four items of subjective physical and sensory functions, and 13 items of mobility abilities. The physical and sensory function items were: (a) Brain disorder-stroke or infraction), (b) Eye disorder-cataract for example, (c) Field of view (FOV) problem, and (d) Ability to walk.

\subsection{Deterioration of physical and sensory functions by age group}

Table 6 shows the deterioration of physical and sensory functions by age group. However, (d) Ability to walk, is not included because of the small number of participants with good ambulatory skills: 12 have difficulty in walking-they can walk 50 meters unassisted; another 6 have difficulty in walking and can manage 50 meters in a wheelchair. In addition, 9 participants are still driving.

Table 6 Deterioration of physical function by each age group

\begin{tabular}{lcccccc}
\hline \hline & \multicolumn{2}{c}{60 to 64} & \multicolumn{2}{c}{65 to 74} & \multicolumn{2}{c}{ Over 75} \\
& Number & $(\%)$ & Number & $(\%)$ & Number & $(\%)$ \\
\hline a. Brain disorder & 3 & $(1.6)$ & 15 & $(5.3)$ & 32 & $(11.3)$ \\
b. Eye disorder & 24 & $(12.9)$ & 62 & $(22.1)$ & $119 \quad(42.3)$ \\
c. FOV problem & 21 & $(11.2)$ & 42 & $(15.4)$ & $78 \quad(28.9)$ \\
\hline
\end{tabular}

\subsection{Deterioration of cognitive sensor functions and mobility abilities}

(1) Methodology

The 13 items of subjective mobility abilities were determined based on the previous report ${ }^{(10)}$ as to which items are often seen affecting the driving characteristics of the elderly 
and dementia sufferers. The 13 items are (A) getting lost on the way, (B) forgetting the reason for going out, (C) ignoring traffic signals and road signs, (D) difficulty in understand road signs, (E) confusing brake and accelerator pedals, (F) becoming distracted by talking with someone, $(\mathrm{G})$ driving in the opposing lane, $(\mathrm{H})$ drifting from side to side of the road while driving, (I) difficulty in parking car in a garage, (J) difficulty in quick thinking, $(\mathrm{K})$ feeling tired while driving, (L) inability to concentrate on driving, (M) failing to negotiate a curve.

(2) Results of deterioration of physical functions and mobility skills

Table 7 shows the chi-square test results of physical functions and mobility skills. The 8 items related to driving ability for participants with eye disorder are significantly higher than for participants without an eye disorder. Items (H) and (I) for participants with brain and eye disorders are significantly higher compared with participants without brain and eye disorders. The table also shows that item (E), (H) and (I) those in the "old-old" age group when compared with the "young-old" age group are significantly lower. However, there is no significantly between participants with an FOV disorder.

Table 7 Disorder and driving skill $p$ value

\begin{tabular}{ccccc}
\hline \hline & Brain disorder & Eye disorder & FOV problem & Young-old VS Old-old \\
\hline (C) & 0.389 & $0.003^{* *}$ & 0.264 & 0.857 \\
(D) & 0.804 & $0.002^{* *}$ & 0.873 & 0.842 \\
(E) & 0.567 & $0.018^{*}$ & 0.208 & $0.030^{*}$ \\
(F) & 0.142 & 0.217 & 0.275 & 0.650 \\
(H) & $0.015^{*}$ & $0.005^{* *}$ & 0.361 & $0.034^{*}$ \\
$(\mathrm{I})$ & $0.027^{*}$ & $0.010^{*}$ & 0.760 & $0.011^{*}$ \\
$(\mathrm{~J})$ & 0.090 & $0.000^{* *}$ & 0.771 & 0.410 \\
(K) & 0.508 & $0.011^{*}$ & 0.581 & 0.939 \\
(M) & 0.266 & $0.041^{*}$ & 0.523 & 0.613 \\
\hline
\end{tabular}

${ }^{*} \mathrm{p}<.05,{ }^{* *} \mathrm{p}<.01$

\subsection{Deteriorating physical and sensor functions, driving skills, and desire to continue driving}

Table 8 shows the participants' decreasing physical and sensor functions, driving skills and their desire to continue to drive, classified by less or equal 4 years and over 5 years. The desire to continue driving among subjects with a brain disorder, eye disorder, FOV disorder was significantly shorter in terms of years compared with subjects without such disorders.

Table 8 Desire (in years) to continue driving

\begin{tabular}{lcccccc}
\hline \hline & $\begin{array}{c}4 \text { or less years } \\
\text { Number (\%) }\end{array}$ & $\begin{array}{c}5 \text { or more years } \\
\text { Number (\%) }\end{array}$ & $\chi^{2}$ value & $p$ value \\
\hline Age & 8 & $(10.7)$ & 14 & $(3.7)$ & 6.43 & 0.011 \\
Brain disorder & 25 & $(33.8)$ & 61 & $(16.6)$ & 11.56 & 0.001 \\
Eye disorder & 21 & $(28.4)$ & 42 & $(11.5)$ & 21.04 & $0.00^{* *}$ \\
FOV problem & & & & & &
\end{tabular}

\section{Focus Group Interview}

\subsection{Surveyed area}

Profiles of the participants of the focus group interview are shown in Table 9. The target areas are the 4 areas included in the questionnaire survey. 
Table 9 Participants of focus group interview

\begin{tabular}{|c|c|c|c|c|}
\hline Area & Number & (Male; Female) & Age & Contents \\
\hline Harue & & $(5 ; 2)$ & $78.2 \pm 3.1$ & $\begin{array}{l}\text { - Family structure (average } 5 \text {, solitary } 1 \text { ) } \\
\text { - Owned car (average } 4 \text { ) } \\
\cdot \text { - Bicycle }\end{array}$ \\
\hline Sakai & & $3 \quad(8 ; 0)$ & $77.3 \pm 4.9$ & $\begin{array}{l}\text { - Family structure (average 4.6) } \\
\text { - Owned car (average } 3.9 \text { ) } \\
\text { - Non-license } 1 \text { person: bicycle }\end{array}$ \\
\hline Hongo & & $7 \quad(4 ; 3)$ & $77.1 \pm 6.9$ & $\begin{array}{l}\text { - Family structure (average } 4.3 \text {, solitary } \\
1 \text { ) } \\
\text { - Owned car (average } 3.3 \text { ) } \\
\text { - Solitary person: bike } \\
\text { - Family structure (average } 3.3 \text { ) }\end{array}$ \\
\hline Nakafuji & & $(9 ; 0)$ & $76.0 \pm 5.2$ & $\begin{array}{l}\text { - Owned car (average } 2.3 \text { ) } \\
\text {-Walking difficulty: } 1 \text { person }\end{array}$ \\
\hline
\end{tabular}

\subsection{Driving behavior in each area}

(1) Driving frequency and purpose

To calculate the driving frequency for each purpose, the purpose (medical, shopping, hobbies, etc.), frequency and trip time was recorded. Figure 8 shows the average round trip time per month in the given areas. The driving purpose frequency is different in each area. In Harue, less time was spent on trips for medical facilities and shopping, while the time spent on work-related trips was longer than in other areas. The overall trip time for Sakai, which is high accessible area for public transport, is shorter than for other areas. In Hongo, which has low accessible for public transport, the trip time for medical, hobbies, shopping is longer than for other areas. Nakafuji, which is located in center of city, is 20 hours a month in each item.

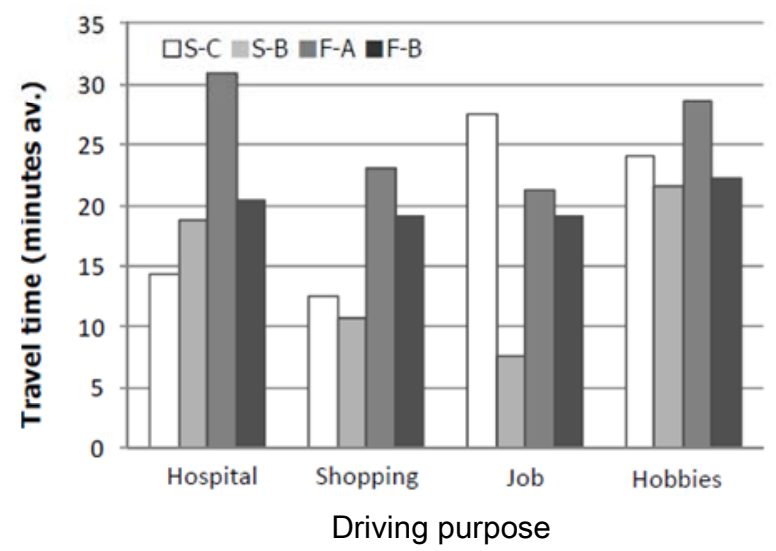

F-A Hongo, F-B Haruyama, S-B Harue, S-C Sakai

Fig. 9 Travel time in each area

(2) Mobility and daily living

On average, it takes participants 5 to 20 minutes to drive to a general hospital or a clinic in the study areas and they have no complaints about it. Also they have no complaints about supermarkets that they can provide food and basic necessities except for the crowded parking lot in Nakafuji. For participants with their own businesses, there is more demand to drive for business reasons. As for type of vehicle, a lightweight truck is commonly used in the Harue and Hongo areas for farming in fields and forestry work. The family car is used mainly in the Nakafuji area, which has fewer parking spaces than in other areas, In the Hongo area, the public transport system is inconvenient. In addition, it is more difficult to go out in winter in Hongo, because there is more snow than in the other areas.

(3) Driving and aging

Most of the participants said that they did not plan to quit driving until they hit their 
mid-80s to 100s. However, some participants realized they would have to give up driving sooner or later. Participants in remote villages face a dilemma in that even if they want to give up driving, they cannot because they need to continue driving for work reasons. Many participants said they had seen unsafe elderly drivers who cannot merge with the flow of vehicle. And participants take care to join the flow of cars, keep a safe distance between oneself and the car ahead etc. by other's unsafe behavior. After they quit driving, the participants said they plan to use taxis, the bus or train, or travel in other people's car as an alternative form of mobility.

(4) What is a car for?

The car was recognized by the participants as a "tool" for jobs such as "going to work" and for "mobility in generality," in addition, the car was consider as having wider meanings, including "an extension of one's body" and "part of one's life." On the other hand, some participants said they "disliked driving" and viewed cars as "potential weapons." One participant said driving is a way to communicate with others, adding that she assumes the role of transporting her family in her car.

\subsection{Factors that reinforce of the intention of participants to give up or continue driving}

Table 11 shows the factors aired in the group interview that reinforce the intention of participants to either quit or continue to drive.

Table 11 Factors reinforcing intention to quit of continue driving

\begin{tabular}{|c|c|c|}
\hline $\begin{array}{c}\text { Reinforc } \\
\text { ement }\end{array}$ & Factor & Item \\
\hline \multirow{3}{*}{$\begin{array}{l}\text { Reinforce } \\
\text { ment to } \\
\text { quit }\end{array}$} & $\begin{array}{l}\text { Deteriorating } \\
\text { body functions } \\
\text { observed in } \\
\text { others }\end{array}$ & Hard of hearing $^{*} /$ Slow reflexes \\
\hline & $\begin{array}{l}\text { Driving skill of } \\
\text { others }\end{array}$ & $\begin{array}{l}\text { Speed is extremely slow or fast / not using turn signals } / \\
\text { dangerous lane changes } / \text { driving in the center of the road } / \\
\text { too serious about driving / dangerous apses of concentration }\end{array}$ \\
\hline & $\begin{array}{l}\text { Personal } \\
\text { factors }\end{array}$ & $\begin{array}{l}\text { Recommendation from family or offers of rides from others } \\
\qquad / \text { stroke, brain disorder }\end{array}$ \\
\hline \multirow{4}{*}{$\begin{array}{l}\text { Reinforce } \\
\text { ment to } \\
\text { continue }\end{array}$} & Job and role & Work $/$ have to take a grandchild to and from their school \\
\hline & Living & food, convenience, easy \\
\hline & Spirituality & recreation $/$ sense of loss $/$ communications \\
\hline & $\begin{array}{l}\text { Alternate } \\
\text { methods }\end{array}$ & $\begin{array}{c}\text { No courtesy bus for hot springs } / \text { No one to ask for a ride with } \\
\text { frequency }\end{array}$ \\
\hline
\end{tabular}

* Effect of hearing impaired driving has not been reported. ${ }^{(11)}$

We assumed that factors reinforcing the idea of giving up a driver's license were observation of the driving skills and behavior of other elderly drivers, recommendations from family, the ready availability of being driven by someone else, and brain disorders - for example an aneurism or a stroke. On the other hand, we assumed that factors reinforcing the idea of continuing to drive were work and family duties, for example, a grandparent has to take a grandchild to and from school, and for daily chores, such as shopping. Mentality also is an important factor, particular for solitary old people, for communication. The last factor is that many people have no alternative means of transportation.

Our interview showed that the overall satisfaction about their current mobility was high among participants. In remote villages that are defined by having $50 \%$ of the population older than 65, more of the respondents (around $48 \%$ ) were older than 75 than in other areas. Cars in such areas are used more frequently more than in the other areas, broken down as other people's cars and participant's own car. 


\section{Necessity of alternative mobility}

Results from the questionnaire survey and the focus group interview clarified the effects of car dependency and the impact of having to stop driving among elderly people in rural areas. From our survey, we found that more than half of elderly participants drive every day with people tending to drive less the older they are. And the satisfaction with current mobility of elderly is lower than younger elderly age group. License holder of elderly with feelings of decreased motor skills (i.e. FOV, aneurisms, strokes, disorder of the eye) awareness a decrease in driving ability. The main reason the elderly drive: is to go shopping, to the hospital, for work, and for hobbies and past-times. To induce the elderly to stop driving, there needs to be awareness against decrease of their real ability in terms of driving skills. Based upon these results, this section summarizes the items required in considering alternative mobility.

- Mobility devices to maintain social and personal relationships: For elderly people living in areas badly served by public transport, it is theoretically possible to solve their mobility problems by having them move to city centers. However, this is not a realistic solution, because the involuntary move could damage social and personal relationships and adversely affect them mentally ${ }^{(12)(13)}$. Therefore, we assume that for the elderly to continue to live long lives and enjoy healthy social and personal relations, it is necessary to consider alternatives to going out to prevent the driving frequency decreases rapidly with aging.

- Mobility devices as an extension of walking: The public transport access of the researched areas in each district is especially low. And the mobility patterns necessary for everyday life, rather than a stopover for migratory pattern and the railway station and bus stops, the car is an extension to walking. In these areas, a long-distance transport system cannot support people's lifestyles. To compensate for the reduced frequency of short-range operations, it is necessary to meet the needs of individual transport systems.

- Use the existing public transport environment: There is awareness of age-related declines in physical functions and is adapted to reduce the speed of action, the driver is willing to continue the operation, small and easy maneuverability cars at low speed to be effective. Moreover, mainly concerned with living in the area by car, since it has a relatively developed road environment, even when a small financial resources can support.

\section{Conclusion}

In this study, we clarified the effects of car dependency and the impact of having to stop driving among the elderly in rural areas. We carried out a questionnaire survey and focus group interviews. We received 1,338 questionnaires back that were sent out to the over-60s in regional cities, which included areas that were accessible and inaccessible by public transport. The focus group interviews were held in four areas in the overall selected area. We found that more than half of elderly drivers drive every day, with people tending to drive less the older they are. The elderly license holder with feeling motor skill decrease such FOV, eye disorder and brain disease) awareness a decrease in driving ability. Moreover, it is clarified that issue of alternative mobility are "mobility devices to maintain social and personal relationships," "mobility devices as an extension of walking" and "use the existing public transport environment". Next, we will compare findings with other areas which have different characteristics public transport system. 


\section{Acknowledgements}

We thank associate professor Hiromi Arita, Fukui Prefectural University, Fukui Prefecture, Fukui City, Sakai City, for their cooperation. This work was supported in part by the KAKENHI 20300194, Japan.

\section{References}

(1) Cabinet office, White Paper on traffic safety in Japan 2010, http://www8.cao.go.jp/koutu/ taisaku/h22kou_haku/gaiyo/genkyo/topics/topic01.html (2010.11).

(2) Society of Automotive Engineers of Japan, Old people driving handbook Car society kind to the old people, Society of Automotive Engineers of Japan, 2005.

(3) Nishimura, S., Case study of governmental action; from the city which aged-rage $34 \%$ - the driving license cessation system- (in Japanese), Rounen Seishin Igaku Zasshi, Vol 19, No.1 (2008), pp.164-168.

(4) Tokoro, M., Problem about license renewal of elderly drivers (in Japanese), Japan Socio-Gerontological Society, Vo.30, No.1 (2008), pp.98-105.

(5) Toyoda, Y., Shigenobu, K. and Ikeda, N., Research on the actual situation of the elderly driver (in Japanese), Japanese Journal of Geriatric Psychiatry, Vol. 19, No.1 (2008-1), pp.138-147.

(6) Kamata, M., Fujii, N. and Akiyama, T., Study on Human Friendly Vehicle Usable for Elderly People (1st Report, Investigation on Physical Characteristics and Life Style of elderly People, and Discussion of User Needs for Vehicle Design), Transaction of the Japan Society of Mechanical Engineers, Vol. 68, No.665 (2002-1), pp.220-227.

(7) Kamata, M., Uneda, M., Terashima, Y., Fujii, N. and Akiyama, T., Study on Human Friendly Vehicle Usable for Elderly People (2nd Report, Proposal of "Silver Vehicle" Concept, and Evaluation of Its Proto Type), Transaction of the Japan Society of Mechanical Engineers, Vol. 68, No.669 (2002-5), pp.145-152.

(8) Kamata, M., Terashima, Y., Naoto, F. and Akiyama, T., Study on Human Friendly Vehicle Usable for Elderly People (3rd Report, Evaluation of silver Vehicle Concept by Town-Mobility Experiment)), Transaction of the Japan Society of Mechanical Engineers, Vol. 68, No.669 (2002-5), pp.153-159.

(9) Fukuoka Prefecture Web Site, http://www.pref.fukuoka.lg.jp/d01/next-generation-car-project2. html, (2011-3).

(10) Arai, Y., Arai, A., Dementia and driving: urgent needs for the development of support schemes for patients and their family caregivers, Japanese journal of clinical medicine, Vol.66, No.1 (2008), pp.467-471.

(11) Bonnie M. Dobbs, Medical Conditions and Driving: A Review of the Literature (1960-2000), DOT HS 809690, http://www.nhtsa.gov/people/injury/research/ medical_condition_driving /pages/TRD.html (2011-5).

(12) Koyano, W., Yabe, T., Nishimura, M., Takagi, K., Ando T., Asakawa, T., Social relationships of seniors living in a local city, Social relationships of seniors living in a local city, Japanese journal of gerontology, Vol. 29, No.1 (2007), pp58-64.

(13) Saito, T., Lee, H, Kai, I., Health and motivation of elderly relocating to a suburban area in Japan, Archives of Gerontology and Geriatrics, Vol. 45, (2007), pp.217-232. 